\title{
Eco-anthropocentric approach in urban planning: European and Russian experience
}

\author{
Zinaida Ivanova ${ }^{1, *}$ \\ ${ }^{1}$ Moscow State University of Civil Engineering, Yaroslavskoye shosse, 26, Moscow, 129337, Russia
}

\begin{abstract}
The article presents an idea that social consciousness should be changed in order to create humanized ecological city environment. This consciousness may be formed being influenced by external conditions: educational activities on creating such environment. The author analyses eco-anthropocentric approach to city territories development in Russia and European countries. Now that ecological problems are becoming more acute and the climate is changing, this approach is the only possible for creation of comfortable and safe environment. This is the way to preserve biosphere for the next generations too. The article observes the legislation in Russia, Germany, Denmark and the Netherlands in terms of obligatory measures to preserve the environment and people's participation in decision-making. The author has conducted sociological studies using questionnaire, focus-groups and interview to find out the respondents' attitude to actions of city government on developing the territories as well as the respondents' recommendations on organizing public hearings concerning city problems. City planners - scientists from research institutes and Master students from Moscow State University of Civil Engineering were the respondents. The author's conclusion is: the legislations of the observed European countries are more developed in terms of environmental protection and concern for people's well-being as compared to Russia. Russia doesn't have separate law on climatic changes. The sociological studies show critical attitude of Russian people to laws and governmental actions, though they haven't showed high activity and determination to act, which means the social consciousness hasn't yet become the base for transformations.
\end{abstract}

\section{Introduction}

In postindustrial society of today biosphere preservation and conditions for people's diversification and self-improvement become the main task. Sustainable development of all the life spheres: place of living, interaction, development and education is provided by complex control technologies. Social and humanitarian technologies are becoming most relevant - technologies of social engineering, artificial social systems control, influence on the society and a person. Their aim is to transform the modern society into open society, to form comfortable living environment, at the same time preserving natural environment for

\footnotetext{
*Corresponding author: ivanovazi@mail.ru
} 
future generations. However changes in people's consciousness are needed for these aims, breaking technocratic mentality. Generation of new mentality is the major plank in current social practice. Formation of postindustrial civilization should be connected not only with technological revolution, but also with mental reformation, criticism and reconsideration of old basic values of technogenic culture (its attitude to nature, strength cult as the basis for transformation, consumer society ideals based on materials' and energy consumption, etc.)" - modern researchers emphasize.

Modern living spaces are urbanized territories with acute ecological problems. It is now generally acknowledged that the reason for all ecological disasters is anthropological elimination of original natural connection of human and biosphere, the choice of technogenic values, i.e. values of innovation and progress, priority for transformation of nature. Humanitarian revolution may become the only way to save humankind from the danger of extinction - a Russian scientist K.K. Kolin.

Today the priority task is creation of humanized and ecological city environment which can influence human's mind, the formation of community-minded personality, who realizes the main role of a human in building ecological environment, including city environment. Scientific novelty of the investigation is in the absence of complex investigations of city environment state, citizens' satisfaction with ecological, social, psychological environment, citizens' opinion if the environment is friendly for the development of individual activity, creativity, ability to change something in the world and in oneself, ability for self-perfection and perfection of the environment.

\section{Literature review}

Relevance and necessity of eco-anthropocentric approach in urban development is connected with the necessity to fundamentally change the conceptual approach to city development, balance of manmade and natural in urban design and planning - humanitarian balance of biotechnosphere. Healthy, esthetic and ecological environment directly influences city life stability, influences the citizens positively and creates the image of comfortable peaceful city; this environment positively influences basic senses (seeing, hearing, and smelling) as natural environmental impacts. This environment provides a person with high living standards, wide possibilities for self-development, encourages communication of citizens and social solidarity.

Neither foreign nor domestic science has presented the problem in such way as it was done in this project. Surely there are researches observing separately anthropocentric approach to city environment development or ecological approach. The first city anthropological investigations were conducted in European science in the $50-60^{\text {th }}$ of the XX century. People's needs were the core of these investigations. Systematic research of ecological situation in cities has begun only in the end of XXth - the beginning of XXIst century. The issues of healthy living environment have begun to be raised due to symptoms of ecological crisis. Ecological topic has become a trend in scientific investigations in the whole world, beginning with philosophic analysis of the situation up to specific proposals on environmental protection. As for the latest literature we can find such presentation of this problem in a work by a group of scientists from Great Britain and Finland "Organising in the Anthropocene: an ontological outline for ecocentric theorizing" [1]

In the latest decade there appeared works presenting complex investigations of anthropological and ecological problems in order to find balance to protect the environment. For example the Hague University of Applied Sciences in Netherlands is conducting such investigations. Moreover authors have investigated the balance of ecological and humanitarian skills of students. In particular, researchers Helen Kopnina and 
Andreea Cocis associate the environmental conditions with ecocentric and anthropocentric values of people $[2,3]$.

Sustainable smart city supposes first of all biosphere compatibility - symbiotic interaction of a city with natural environment. Biosphere preservation depends on the progress of humanistic in a human. Such a scientific approach increases the value of human personality, his or her education, qualification, health. A smart city is created by smart and responsible people - it supposes smart urban development and city regulation, creation of diverse and active daily life.

Eco-anthropocentric approach to urban development called biosphere compatibility of cities and settlements is being developed by a member of Russian Academy of Architecture and Construction Sciences V.A. Ilyichev and his research team. In frames of biosphere compatible paradigm they count humanitarian balances of biotechnosphere between: a) biosphere life potential, population and number of places meeting its needs in regions; $b$ ) needs of people and technosphere in biosphere resources and possibility of regional biosphere to meet these needs $[4,5]$. Scientific journals raise questions of the necessity to form ecological consciousness based on eco-anthropocentric approach more and more often [6]. This approach has become particularly relevant in connection with climate change [7$10]$.

\section{Research goals and methods}

How to form ecological, safe environment mitigating negative consequences of climate change and preventing ecological crises? Who will form it? [11]. People who professionally deal with urban planning, maintaining humanitarian balance of biotechnosphere should become the main acting persons. First of all these are people creating regulatory documents for comfortable living environment who are managing city development, specialists in city and municipal management, urban planners and people who are getting such education at the moment $[12,13]$.

Therefore the main research methods in this study are:

1) Document analysis, secondary data analysis. With the help of these method scientific publications, legislations, governmental regulations, strategies of city and regional development, general layouts and concrete management activities were analyzed.

2) Sociological methods. Using them the level of ecological consciousness on citizens is educed as well as readiness of citizens to act in compliance with ecoanthropocentric approach to regional development. In October-November 2018 the author conducted sociological research: interview, focus groups, opinion poll of scientists-urban planners from scientific institutes of urban development, Master students of Moscow State University of Civil Engineering: future urban planners and architects, young active Muscovites.

\section{Research results}

The conducted research of laws of different countries, governmental decrees allowed to identify the attitude to nature and human in different countries.

In Town-Planning Code of Germany we can see the attention of the government to citizen's interests and to biosphere preservation. Environmental issues gain great importance in regional development plans (municipal land management). "Municipal governments observe ecological consequences of urban development plans in order to reveal unforeseen negative impacts and be able to take counteractions" [14]. 
Eco-anthropocentric approach to city development plans is approved in part 7 chapter 2 of Town-Planning Code: "If it is expected that urban development plans, city sanation or city reconstruction are going to influence personal life of people living or working in the area negatively, the municipal government should develop suggestions how this influence may be minimized or evaded and discuss it with people" [14].

In Denmark and in all the Scandinavian countries the legislation regulates the environmental effect of human activity (trade, manufacturing, municipal services, etc.). The Danes do not draw a clear boundary between human health care and environmental protection, because they believe that concern for the environment is the concern for human health. Surely this approach is the best example of eco-anthropocentric approach to living environment. Environmental activity is the priority area of Danish policy and law. Danish citizens strongly support the governmental ecological policy. Social studies show that about $90 \%$ of the Danes believe environmental issues are among the most current and important social and political problems, which should be solved by joint efforts of the society [15]. All the projects having ecological consequences are subject to public discussion.

Denmark has a developed system of environmental legislation. The Act on Protection of Environment is one of the main ecological laws for environmental protection and protection of human health. Danish Environmental Protection Agency (DEPA) administrates environmental legislation execution.

Another evidence of how important these problems are for Denmark is that the Aarhus Convention was signed in Denmark ("Regarding access to information, public participation and access to justice, in governmental decision-making processes on matters concerning the local, national and transboundary environment"). The aim of the Convention is protection of human rights for favorable and healthy environment, access to information, participation of citizens in decision-making and for justice in environmental issues [16].

Human rights for favorable safe environment are protected also in other European countries.

In Norway the Law on urban planning and construction also regulates forms of public involvement (information, consult, active participation) and instruments (workshops, public hearings, etc). According to urban planning requirements stated in the Law on urban planning and construction in provinces the responsible governmental bodies and interested organizations should have opportunity to take active part in planning process. In future the community will get general information on urban planning process and will have opportunity to express their opinion and make suggestions on the topic.

The Law on Social Support is in force in the Netherlands. It is one of the most interesting examples of public participation in city environment. Citizens' participation in the state policy both on local and state level is in the basis of the whole state policy in the Netherlands. The Law obligates city authorities to engage the community in city policy development and implementation. The community may choose from different variants of participation to create "the ideal" city organization. The law states that any governmental decision should undergo a special procedure - public discussion - before this decision is taken.

Russia also has a number of environmental laws. For example, Federal law on environmental protection (amended January $1^{\text {st }}, 2020$ ), Federal Law on environmental assessment (amended December 27 $7^{\text {th }}, 2019$ ); Town-Planning Code of the Russian Federation (amended 27.12.2019).

Unfortunately these laws don't state explicitly public participation and legal security of citizens' comments and requests. For example decisions of public hearings on urban development projects with negative environmental and social impact have no legal basis. They may not be taken into consideration when approving town-planning projects. The opinion poll of researchers - urban planners working in scientific institutes and Master 
students - urban planners and architects shows that citizens are critical about governmental actions in urban development.

The majority of the respondents believe that only economic criteria are taken into account when approving town-planning projects: such as investment value of a project, capitalization growth of residential and commercial property and the interests of the city in the use of this land. Their municipal authority is put in the forefront. $67 \%$ of urban planners working in scientific institute also believe that city authorities are guided only by economic reasons, i.e. financial gains for exact groups of people. Everything else pales into insignificance. Even space-planning criteria, which are major for city planners, were chosen only by $22 \%$ of respondent. Only $10 \%$ of respondents think social factors (favorable living conditions, safety, employment) are taken into account when developing and approving projects. $5 \%$ of respondents (which is extremely small number of specialists) are sure that ecological factors are taken into account (natural value, normative quality of the environment, etc.) (Fig.1).

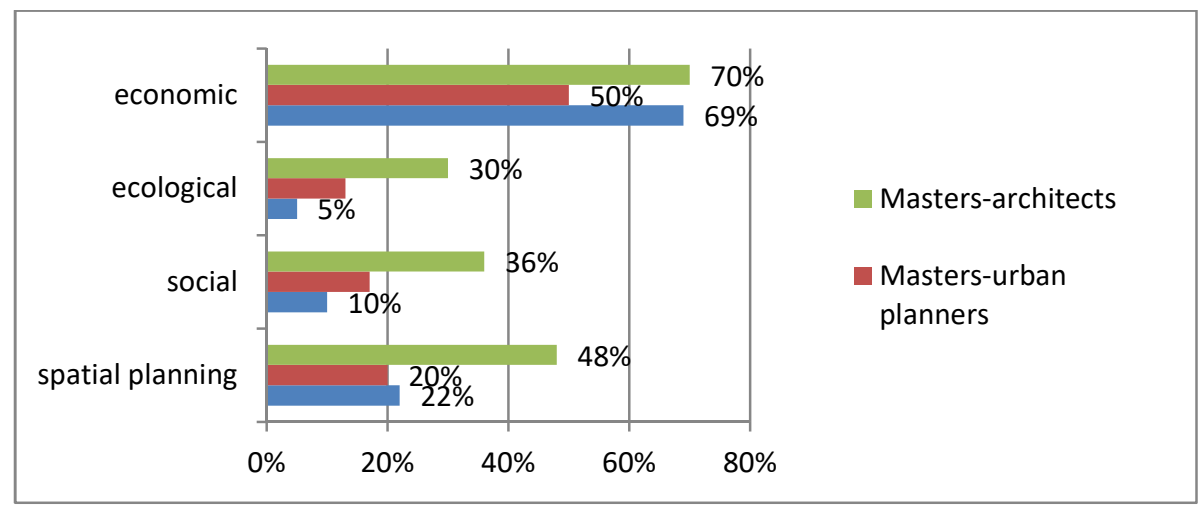

Fig. 1. Answers for the question: "Which criteria you think are taken into account by municipal authorities when making decisions on urban planning projects?"

Consequently the respondents think all urban development projects which may influence biosphere should be discussed in public hearings (Fig.2).

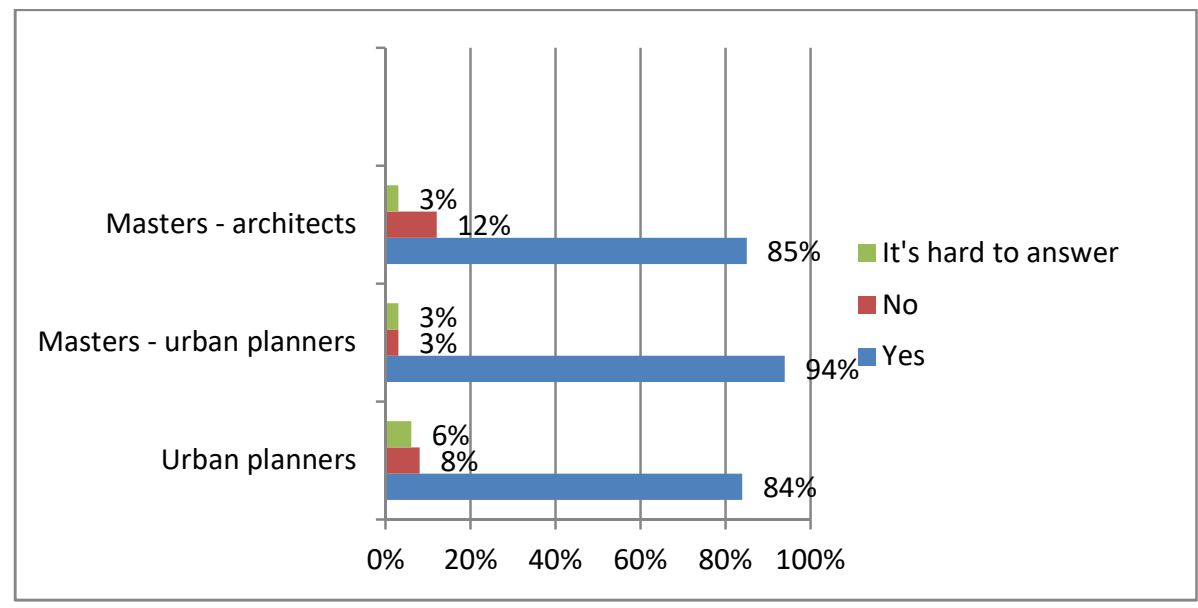

Fig. 2. Answers to the question: "Do you think urban planning projects threatening city environment should be brought up for public discussion? 


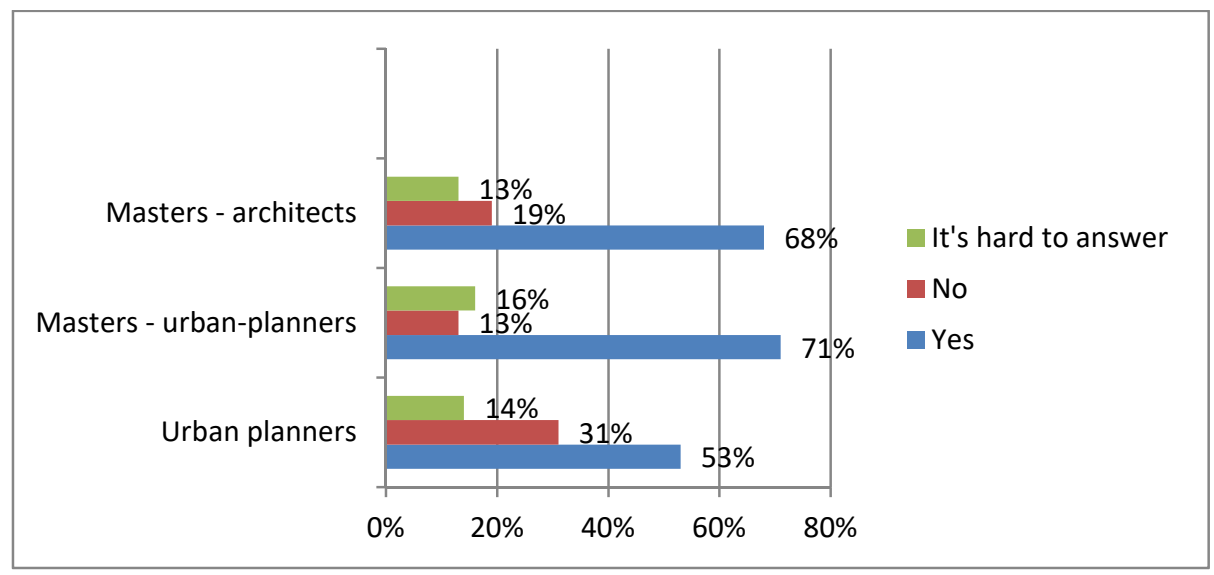

Fig. 3. Answers to the question: "Do you think all urban development projects should be followed by independent examination by professionals?"

The respondents believe projects should pass independent examination by professionals to get qualified opinion if they have negative impact.

City activists - members of initiative group of Muscovites - are more categorical. They criticize the existing laws on public participation in decision-making and draw attention to the facts of governmental disregard of citizens' opinion when approving town-planning projects. Nevertheless the respondents haven't shown readiness to make active steps to participate in decision-making, explaining that "the authorities will have their own way anyway".

\section{Conclusions}

As a result of the investigation the author revealed that eco-anthropocentric approach to urban development hasn't yet become reality in Russia. Public participation in decisionmaking on the subject of urban development projects is being ignored. Urban development projects do not take into account negative impact of climate changes, risks of environmental disasters. We don't have urban development strategies in the conditions of climatic changes. Meantime in Europe close territorial cohesion ensures the possibility of protection from climate change consequences. The Treaty of Lisbon and new EU strategy introduced new dimension: territorial unity (Territorial Agenda of the European Union 2020). The consequences of climatic changes are not limited by administrative boundaries, so new forms of cooperation between countries and regions are being developed. Russia needs to study European strategies of safe urban development being a territory with different climatic zones and high level of carbon emission and pollution of cities.

Russian urban planners need modern approaches to city development, among which eco anthropocentric approach is the core. The society needs constant information on the real environmental state. Awareness and concern of citizens, responsibility for living environment is an important step to its preservation.

\section{References}

1. P. Heikkurinen, J. Rinkinen, T. Järvensivu, K. Wilén, T. Ruuska. Journal of Cleaner Production 113(1), 705-714 (2016). ISSN 0959-6526 
2. H. Kopnina, A. Cocis. European Journal of Sociology and Anthropology 2(1), (2017) doi: $10.20897 /$ ejsa.201702

3. H. Kopnina. Environment, Development and Sustainability 15(3), 607-623 (2013) DOI: $10.1007 / \mathrm{s} 10668-012-9395-\mathrm{Z}$

4. V. Ilyichev, V. Kolchunov, S. Emelyanov, N. Bakaeva, Applied Mechanics and Materials 725-726, $1224-1230$

(2015). https://doi.org/10.4028/www.scientific.net/AMM.725-726.1224

5. V. Ilyichev, V. Kolchunov, S. Emelyanov, N.Bakaeva. IOP Conference Series Materials Science and Engineering 463(3), 032011 (2018) DOI: 10.1088/1757899X/463/3/032011

6. N.V. Bakaeva, S.A. Vorobyov, I.V. Chernyaeva. IOP Conference Series: Materials science and engineering, 012193 (2017) DOI: 10.1088/1757-899X/262/1/012193

7. S.Grafakos, G.Viero, D.Reckien, K.Trigg et al. Renewable and Sustainable Energy Reviews 121, 109623 (2020) https://doi.org/10.1016/j.rser.2019.109623

8. G. Özerol, N. Dolman, H. Bormann, et.al. Sustainable Cities and Society 55, 102066 (2020) https://doi.org/10.1016/j.scs.2020.102066

9. K. S. Wolske, P. C. Stern. Psychology and Climate Change, 127-160 (2018) https://doi.org/10.1016/B978-0-12-813130-5.00007-2.

10. E. Sharifi, M.Larbi, H. Omrany, J. Boland. Journal of Cleaner Production 254, 120035. (2020) https://doi.org/10.1016/j.jclepro.2020.120035

11. U. Beck, Theory, Culture \& Society 27(2-3), 254-266 (2010) DOI $10.1177 / 0263276409358729$

12. Zh. Mi, D. Guan, Zhu Liu,. Jingru Liu et al. Journal of Cleaner Production 207, 582589 (2019) https://doi.org/10.1016/j.jclepro.2018.10.034

13. L. Gidhagen, J. Olsson, J. H.Amorim, C. Asker et. al. Urban Climate 31, 100549 (2020) https://doi.org/10.1016/j.uclim.2019.100549

14. Federal Building Code (BauGB). https://germanlawarchive.iuscomp.org/?p=649

15. H. Djurhuus., P. Hemmer, A.S.K. Vilsbøll, Enviromental law and practice in Denmark: overview. https://uk.practicallaw.thomsonreuters.com/0-5220619? transitionType $=$ Default\&contextData $=($ sc. Default $) \&$ firstPage $=$ true \&bhcp $=1$

16. Convention on Access to Information, Public Participation in Decision-Making and Access to Justice in Environmental Matter [The Aarhus Convention]. https://ec.europa.eu/environment/aarhus/;

https://www.un.org/ru/documents/decl_conv/conventions/orhus.shtml 